\title{
Rancang Bangun Indoor Positioning System berbasis Wireless Smartphone menggunakan Teknik Global Positioning System dengan Metode Absolut
}

\section{(The Design of An Indoor Positioning System Prototype Using Wireless Smartphone by Modify} Absolute Method of The Global Positioning System)

\author{
Jamaluddin, Agung Tjahjo Nugroho, Wenny Maulina \\ Jurusan Fisika, Fakultas Matematika dan Ilmu Pengetahuan Alam, Universitas Jember (UNEJ) \\ Jln. Kalimantan 37, Jember 68121 \\ E-mail: agungtnugroho@unej.ac.id
}

\begin{abstract}
Abstrak
Indoor Positioning System (IPS) merupakan teknologi informasi untuk menentukan posisi objek di dalam ruangan berbasis wireless smartphone. Perangkat yang digunakan dalam penelitian ini adalah empat unit smartphone, satu smartphone sebagai transmitter, dan tiga smartphone lainnya sebagai receiver. Tujuan penelitian ini adalah mendapatkan model dan tingkat akurasi dari IPS berbasis wireless smartphone menggunakan teknik Global Positioning System (GPS) dengan metode absolut. Penelitian ini dilakukan dengan membuat dua model IPS dan melakukan pengukuran intensitas sinyal Wi-Fi berdasarkan masing-masing model IPS yang telah dibuat untuk mendapatkan persamaan linier antara jarak dan intensitas sinyal Wi-Fi. Persamaan linier yang didapatkan dari model IPS digunakan untuk menentukan jarak antara receiver dan transmitter berdasarkan intensitas sinyal Wi-Fi yang terukur pada saat pengujian model, kemudian informasi jarak tersebut digunakan untuk menentukan posisi objek (transmitter). Hasil penelitian menunjukkan bahwa Model 1 IPS berbasis wireless smartphone mampu mengestimasi posisi dengan rata-rata tingkat kesalahan mencapai $4,46 \mathrm{~m}$ dan tingkat akurasinya mencapai $76,51 \%$. Model 2 IPS mampu mengestimasi posisi dengan rata-rata tingkat kesalahan 9,68 m dengan tingkat akurasinya mencapai 49,03\%. Berdsarakan hasil tersebut, dapat disimpulkan bahwa model 1 IPS memiliki tingkat akurasi yang lebih baik untuk mengestimasi posisi objek daripada model 2 IPS.
\end{abstract}

Kata Kunci: Global positioning system (GPS), indoor positioning system (IPS), wireless smartphone.

\section{Abstract}

Indoor Positioning System (IPS) is an information technology to determine the position of objects in the room base on wireless smartphone. The device used in this research is four units of smartphones, one smartphone as a transmitter, and three other smartphones as a receiver. The focus of this research is to get the design and accuracy level of IPS base on wireless smartphone using Global Positioning System (GPS) technique with absolute method. This research was conducted by making two IPS design and measuring the intensity of Wi-Fi signal based on each IPS model that has been made to obtain linear equations between the distance and intensity of Wi-Fi signal. The linear equations obtained from the IPS design are used to determine the distance between the receiver and the transmitter based on the intensity of the measured Wi-Fi signal during the design test, then the distance information is used to determine the position of the object (transmitter). The results showed that design of 1 IPS base on wireless smartphone is able to estimate the position with an average error rate reaches $4.46 \mathrm{~m}$ and the accuracy rate reaches $76.51 \%$. Design of 2 IPS is able to estimate the position with an average error rate of $9.68 \mathrm{~m}$ with an accuracy rate of $49.03 \%$. Based on these results, it can be concluded that design of 1 IPS has a better accuracy level to estimate the position of the object than the design 2 IPS.

Keywords: Global positioning system (GPS), indoor positioning system (IPS), wireless smartphone .

\section{PENDAHULUAN}

Sebuah sistem tracking yang umum dipakai adalah menggunakan global positioning sistem (GPS). GPS merupakan salah satu fitur pada smartphone yang memudahkan pengguna untuk mengetahui koordinatnya, yaitu berupa data latitude dan longitude. GPS ini digunakan untuk menentukan posisi dipermukaan bumi dengan bantuan satelit [8]. Satelit GPS berputar mengelilingi bumi selama 12 jam di dalam orbit yang akurat dan mengirimkan sinyal informasi ke bumi. Receiver GPS menerima sinyal informasi tersebut dan menggunakan perhitungan triangulasi untuk menghitung lokasi pengguna dengan tepat. Receiver GPS membandingkan waktu sinyal dikirim dengan waktu sinyal diterima. Setelah informasi posisi didapatkan sehingga diketahui berapa jarak dari satelit dan posisi pengguna. Pseudorange merupakan suatu kode pengamatan yang menggunakan perbedaan antara waktu transmisi di satelit dan waktu penerima pada receiver GPS di bumi [5]. Menurut Wells [10] persamaan pengamatan untuk pseudorange ditunjukkan pada persamaan (1).

(1)

$$
p=r+c(d t-d T)
$$

\section{Keterangan:}

$p$ adalah pseudorange,

$r$ adalah jarak antara satelit GPS dengan receiver GPS,

$c$ adalah kecepatan cahaya,

$d t$ adalah waktu pengiriman sinyal satelit GPS,

$d T$ adalah waktu penerimaan receiver GPS. 
Persamaan jarak antara satelit GPS dengan receiver diberikan oleh pesamaan (1) berikut,

(2)

$$
r=\sqrt{\left(x_{s}-x\right)^{2}+\left(y_{s}-y\right)^{2}}
$$

\section{Keterangan:}

$r$ adalah jarak antara satelit GPS dengan penerima,

$\left(x_{s}, y_{s}\right)$ adalah koordinat satelit GPS,

$(x, y)$ adalah koordinat receiver.

Namun sistem tracking berbasis GPS seperti ini bekerja dengan bergantung penuh pada sinyal-sinyal satelit, sehingga pada saat ingin melacak atau mengetahui posisi suatu objek yang berada didalam gedung sistem ini akan memiliki keakurasian yang rendah, karena receiver hanya menerima sinyal dari beberapa satelit. Seperti yang diketahui, pada prinsipnya sebuah GPS receiver menerima informasi dari tiga buah satelit untuk menentukan posisi. GPS receiver berada dalam line of sight (LoS) terhadap ketiga satelit tersebut untuk menentukan posisi, hal ini menyebabkan GPS hanya ideal untuk digunakan dalam outdoor positioning Habibi dan Shiddiqi [3]. Sehingga GPS tidak ideal untuk digunakan sebagai indoor positioning. Perkembangan teknologi terbaru untuk mengatasi masalah tingkat akurasi yang rendah pada GPS ketika digunakan di dalam gedung yaitu diciptakan indoor positioning system (IPS).

Indoor positioning system (IPS) merupakan teknologi informasi yang berfungsi untuk menemukan posisi suatu objek di dalam gedung Putra, dik. [7]. IPS memanfaatkan teknologi nirkabel yang saat ini hampir terpasang di gedung-gedung pendidikan, perkantoran, dan pusat perbelanjaan, sistem ini dapat menemukan posisi objek dalam ruangan, baik berupa orang, benda, dan lain-lain. Sistem IPS bekerja dengan cara memanfaatkan sinyalsinyal Wi-Fi yang dipancarkan oleh beberapa access point (transmitter). Sinyal yang dipancarkan oleh transmitter kemudian diterima oleh receiver, pada receiver sudah terinstal sebuah aplikasi pengukur intensitas sinyal Wi-Fi yang diterimanya dari transmitter. Sistem akan menerima input dari receiver berupa kekuatan sinyal Wi-Fi yang kemudian akan mengeluarkan output berupa koordinat posisi receiver.

Trilaterasi merupakan salah satu metode utama untuk mengestimasi posisi objek yang bergerak di dalam gedung dengan Wi-Fi. Metode trilaterasi bekerja dengan menghitung jarak objek $\left(1_{1}, l_{2}, l_{3}\right)$ dari tiga titik yang diketahui $\left(\mathrm{A}_{1}, \mathrm{~A}_{2}, \mathrm{~A}_{3}\right)$, yang biasanya titik tetap dengan koordinat yang telah diketahui untuk digunakan menentukan posisi objek seperti yang ditunjukkan pada Gambar 1. Metode ini banyak digunakan dalam survei GPS. Receiver GPS menggunakan metode trilaterasi untuk mengetahui posisi, kecepatan, elevasi dan lain-lain. Dalam indoor positioning system (IPS), koordinat access point dianggap sebagai referensi tetap dan database untuk menyimpan. Lokasi dari access point harus ditetapkan terlebih dahulu, termasuk koordinat access point dan alamat media access control (MAC) masing-masing access point [4].

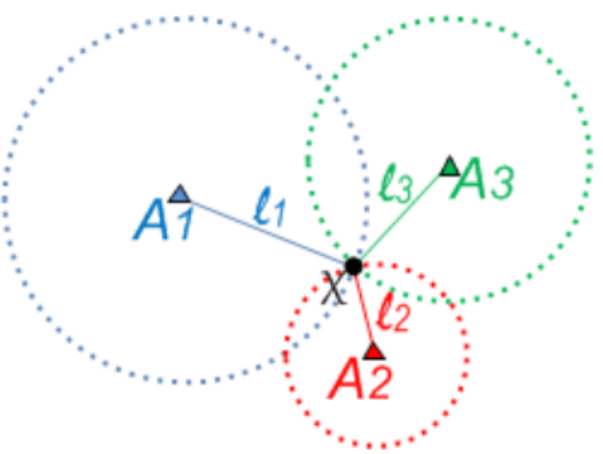

Gambar 1. Trilaterasi GPS (Sumber: Hu, 2013)

Penelitian mengenai IPS pernah dilakukan oleh Perdana, dkk. [6] yang meneliti tentang implementasi Indoor Positioning System berbasis smartphone dengan penambahan access point untuk studi kasus gedung teknik informatika ITS. Pada sistem IPS seperti saat ini dibutuhkan beberapa access point/Wi-Fi router untuk memancarkan sinyal Wi-Fi. Sehingga diperlukan adanya solusi untuk mengatasi permasalahan pencarian objek di dalam gedung yang memiliki sedikit access point atau tidak memiliki access point sama sekali.

Berdasarkan permasalahan di atas, maka penulis ingin merancang sebuah IPS berbasis wireless smartphone dengan sumber Wi-Fi yang tidak berasal dari access point namun melalui fitur hotspot pada smartphone (transmitter). IPS di bangun dengan mengadopsi prinsip kerja dari GPS yaitu dengan menggunakan metode absolut. Metode absolut adalah metode yang digunakan GPS dalam penentuan posisi hanya menggunakan satu alat receiver GPS [2]. Karakteristik dari metode absolut ini yaitu satelit-satelit mengirim sinyal secara terus menerus berupa posisi satelit, waktu, dan lain-lain. Receiver GPS menerima sinyal dan menghitung jarak ke satelit tersebut, dan kemudian receiver GPS mengkalkulasi posisi receiver GPS [1]. Pada penelitian ini dilakukan penentuan posisi objek yaitu posisi transmitter dengan menggunakan prinsip penentuan posisi metode absolut pada GPS. Sehingga dengan memanfaatkan satu sumber sinyal Wi-Fi saja sudah dapat menemukan posisi objek meskipun pada dasarnya Wi-Fi belum dirancang untuk penentuan posisi, namun gelombang radio yang dipancarkan dapat digunakan untuk estimasi penentuan posisi dengan memanfaatkan kekuatan sinyal Wi-Fi yang ditangkap oleh smartphone lainnya (receiver).

\section{METODE PENELITIAN}

Model indoor positioning system (IPS) dalam penelitian ini dirancang menjadi dua model. Model 1 IPS seperti yang ditunjukkan pada Gambar 2. Penentuan persamaan pada model 1 IPS dilakukan dengan mengukur intensitas sinyal Wi-Fi pada masing-masing receiver setiap perpindahan $1 \mathrm{~m}$ menjauhi transmiter. Semua receiver bergerak menjauhi transmiter hingga jarak antara receiver dan transmiter sebesar $20 \mathrm{~m}$. Sedangkan untuk model 2 IPS ditunjukkan pada Gambar 3, penentuan persamaan pada model 2 IPS ini juga dilakukan dengan pengukuran intensitas sinyal Wi-Fi pada receiver setiap perpindahan $1 \mathrm{~m}$, namun hanya salah satu receiver (receiver 2) yang bergerak menjauhi transmitter, sedangkan receiver yang lain (receiver 1 dan 3 ) 
tetap pada jarak referensi tertentu. Jarak receiver 1 dan 3 terhadap transmitter yaitu $3 \mathrm{~m}$. Pengukuran intensitas Wi-Fi dilakukan hingga receiver yang bergerak mencapai jarak antara receiver dan transmiter $20 \mathrm{~m}$. Hasil pengukuran Intensitas sinyal Wi-Fi pada jarak $1 \mathrm{~m}-20 \mathrm{~m}$ dianalisis menggunakan regresi linier untuk mendapatkan persamaan linier antara jarak dengan intensitas sinyal Wi-Fi seperti yang ditunjukkan pada persamaan 2 .

$$
I=m d_{i j}+c
$$

dengan $I$ adalah intensitas sinyal Wi-Fi yang diterima oleh receiver, $m$ adalah gradien garis, $d_{i j}$ adalah jarak antara transmiter dan receiver, dan $c$ adalah konstanta.

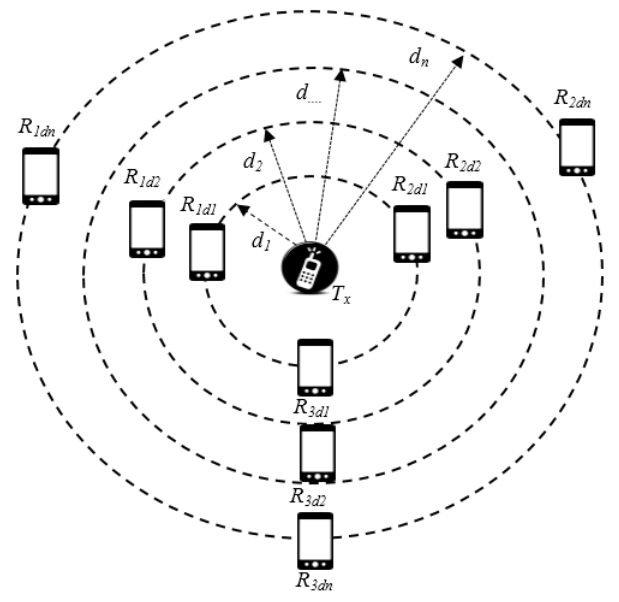

Gambar 2. Model 1 IPS

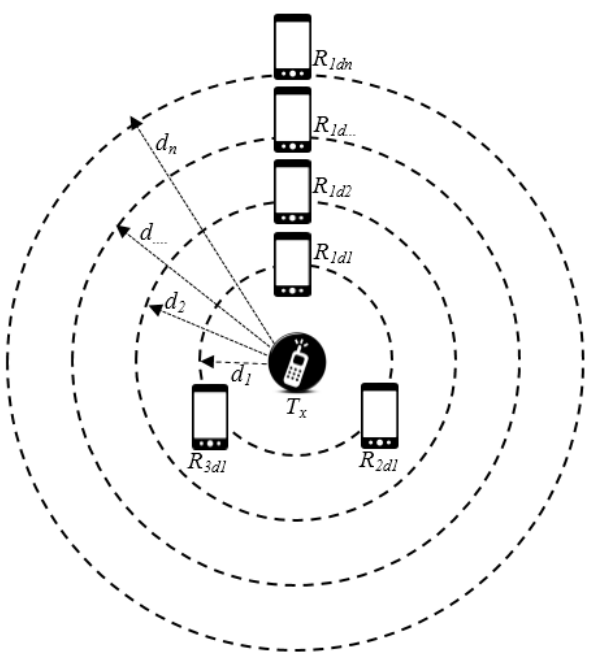

Gambar 3. Model 2 IPS

Setelah pembuatan model IPS dan mendapatkan persamaan pada masing-masing model IPS, tahapan selanjutnya adalah melakukan pengujian pada model IPS yang sudah dibuat. Pengujian model IPS bertujuan untuk mengetahui seberapa baik tingkat akurasi dari masingmasing model IPS yang sudah dibuat. Pengujian model IPS dilakukan dengan membuat suatu area pengujian model IPS (area of investigation) dengan ukuran panjang $20 \mathrm{~m}$ dan lebar $20 \mathrm{~m}$ yang dibagi oleh pixle dengan ukuran $1 \mathrm{~m}$ x $1 \mathrm{~m}$ seperti ditunjukkan pada Gambar 4. Setelah pembuatan area of investigation selesai, dilanjutkan dengan meletakkan 8 titik transmiter secara acak yang akan diestimasi posisinya seperti ditunjukan pada Gambar 5. Receiver juga disebar secara acak dalam area of investigation seperti ditunjukkan pada Gambar 6. Setelah 8 titik transmitter ditentukan, penelitian dilanjutkan dengan pengukuran intensitas sinyal pada masing-masing receiver untuk setiap titik transmitter dimulai dari titik T1 hingga T8.

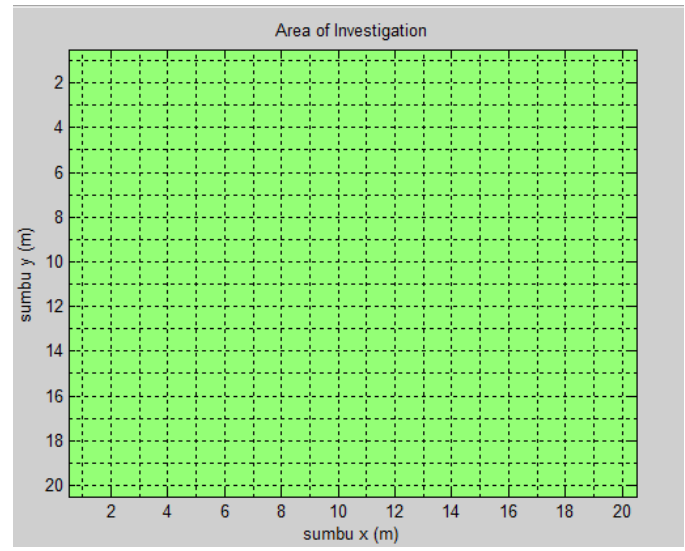

Gambar 4. Area of investigation IPS berbasis wireless smarphone

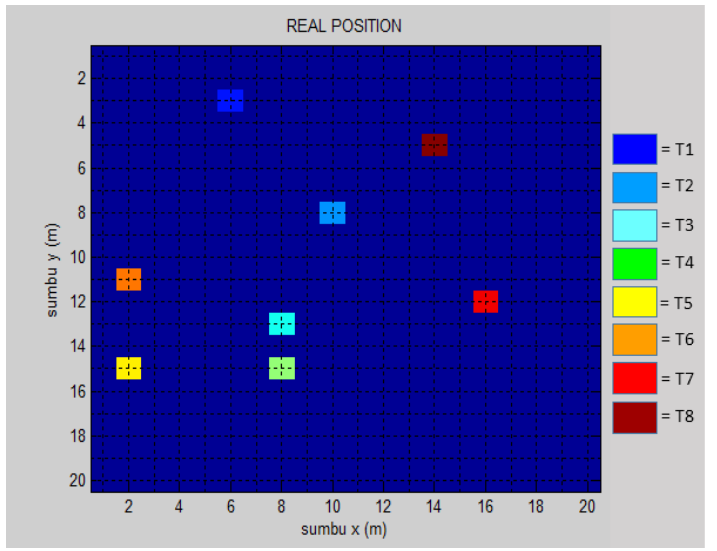

Gambar 5. Posisi asli sebaran titik transmiter dalam area of investigation

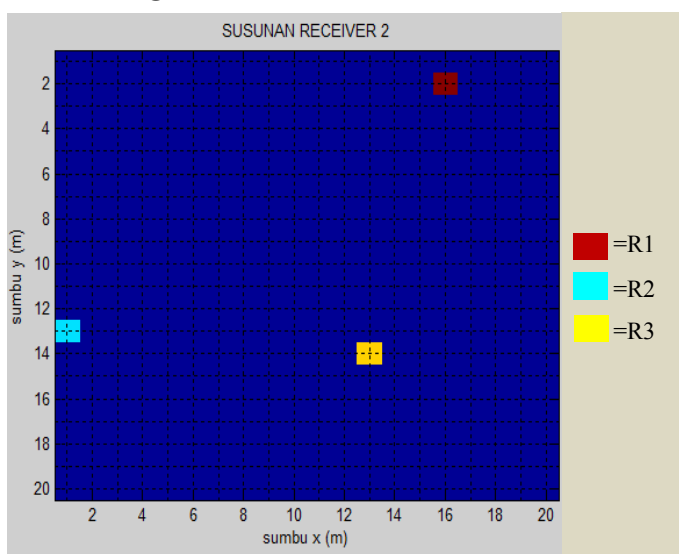

Gambar 6. Susunan receiver dalam area of investigation

Teknik RSSI menggunakan model penentuan jarak dengan mengukur kuat sinyal yang diterima oleh receiver yang dikirim oleh transmitter. Kuat sinyal dalam satuan $\mathrm{dBm}$, merupakan perambatan sinyal dari satu lokasi ke 
lokasi lain. Jarak dalam penelitian ini didapatkan dari persamaan linier antara jarak dengan intensitas sinyal Wi-Fi pada masing-masing model kalibrasi IPS seperti pada persamaan (3.1). Sehingga dengan mendapatkan nilai intensitas sinyal Wi-Fi (I) saat pengujian model dapat mengetahui jarak antara transmiter dengan receiver yang selanjutnya informasi jarak tersebut dapat digunakan untuk estimasi posisi transmitter.

Tahap Estimasi Posisi, pada tahap ini dilakukan proses kalkulasi posisi transmitter berdasarkan informasi jarak dan koordinat posisi yang didapat dari receiver. Penentuan posisi sebuah titik bisa didekati dengan tiga buah titik atau lebih, dimana ketiga titik diasumsikan sebagai tiga buah lingkaran dengan koordinat titik pusat masing-masing yaitu $\left(\left(x_{R 1}, y_{R 1}\right),\left(x_{R 2}, y_{R 2}\right),\left(x_{R 3}, y_{R 3}\right)\right)$ yang mempunyai jari-jari $\left(d_{R 1}, d_{R 2}, d_{R 3}\right)$ dan ketiga lingkaran tersebut saling bersinggungan terhadap sebuah titik $\mathrm{B}_{1}\left(x_{T}, y_{T}\right)$, seperti pada Gambar 3.1. jika diasumsikan setiap titik pusat lingkaran adalah receiver $j$ dan titik yang bersinggungan oleh tiga lingkaran tadi adalah transmitter $i$, maka merujuk kepada persamaan jarak antara dua titik $i$ dan $j$ secara umum dapat dituliskan sebagai:

$$
\hat{d}_{i j}^{2}=\left(x_{i}-x_{j}\right)^{2}+\left(y_{i}-y_{j}\right)^{2}
$$

Algoritma lokasi hiperbolik dua dimensi digunakan untuk mendapatkan koordinat estimasi posisi transmitter $i$ [9]. Algoritma ini dapat mengkonversi persamaan non linier (3) menjadi bentuk persamaan linier agar dapat dengan mudah dicari solusinya.

Jika $R_{j}=x_{j}^{2}+y_{j}^{2}$ adalah komponen receiver $j$ dan $T_{i}=x_{i}^{2}+y_{i}^{2}$ adalah komponen transmitter $i$, maka persamaan (3) dapat dituliskan dalam bentuk linier sebagai berikut:

$$
\hat{d}_{i j}^{2}-R_{j}=-2 x_{i} x_{j}-2 y_{i} y_{j}+T_{i}
$$

Selanjutnya dengan $j=1,2, \ldots M$ receiver, maka persamaan (4) dapat dikembangkan menjadi:

$$
\begin{aligned}
& \hat{d}_{i 1}^{2}-R_{1}=-2 x_{i} x_{1}-2 y_{i} y_{1}+T_{i} \\
& \hat{d}_{i 2}^{2}-R_{2}=-2 x_{i} x_{2}-2 y_{i} y_{2}+T_{i} \\
& \hat{d}_{i M}^{2}-R_{M}=-2 x_{i} x_{M}-2 y_{i} y_{M}+T_{i}
\end{aligned}
$$

Dalam bentuk matriks dapat dituliskan sebagai $b=G Z$ dengan

$$
b=\left(\begin{array}{l}
\hat{d}_{i 1}^{2}-R_{1} \\
\hat{d}_{i 2}^{2}-R_{2} \\
\vdots \\
\hat{d}_{i M}^{2}-R_{M}
\end{array}\right), G=\left(\begin{array}{ccc}
-2 x_{1} & -2 y_{1} & 1 \\
-2 x_{2} & -2 y_{2} & 1 \\
\vdots & \vdots & \vdots \\
-2 x_{M} & -2 y_{M} & 1
\end{array}\right)
$$

dan

$$
Z=\left(x_{i}, y_{i}, T_{i}\right)^{T}
$$

Dimana estimasi posisi transmitter dapat dicari dengan solusi least square dari bentuk matriknya, yaitu
$Z=\left(G^{T} G\right)^{-1} G^{T} b$. Dengan koordinat posisi dari transmitter $i$ adalah $\left(x_{i}, y_{i}\right)=(Z(\mathbf{1}), Z(2))$. Pengolahan data hasil eksperimen dilakukan dengan menggunakan software Matlab R2014a.

\section{HASIL DAN PEMBAHASAN}

Gambar 7 merupakan grafik karakteristik model 1 IPS berbasis wireless smartphone. Grafik tersebut merepresentasikan sebaran data dari model 1. Karakteristik masing-masing receiver berbeda dalam menerima intensitas sinyal yang dikirim oleh transmiter. Daya terima receiver 1 tidak stabil pada jarak dekat yaitu $1 \mathrm{~m}$ dengan transmiter, untuk jarak $2 \mathrm{~m}-17 \mathrm{~m}$ receiver 1 mulai stabil dan mengalami peningkatan pada jarak $18 \mathrm{~m}$ yang kemudian tidak stabil hingga jarak $20 \mathrm{~m}$. Receiver 2 merupakan receiver dengan daya terima yang stabil dari jarak dekat hingga jarak $13 \mathrm{~m}$ dan mengalami peningkatan pada jarak $14 \mathrm{~m}$, namun untuk jarak diatas $14 \mathrm{~m}$ receiver 2 tidak stabil. Begitupun dengan receiver 3 yang mempunyai daya terima intensitas sinyal Wi-Fi stabil hingga jarak $11 \mathrm{~m}$ dari transmiter dan tidak stabil pada jarak diatas diatas $11 \mathrm{~m}$.

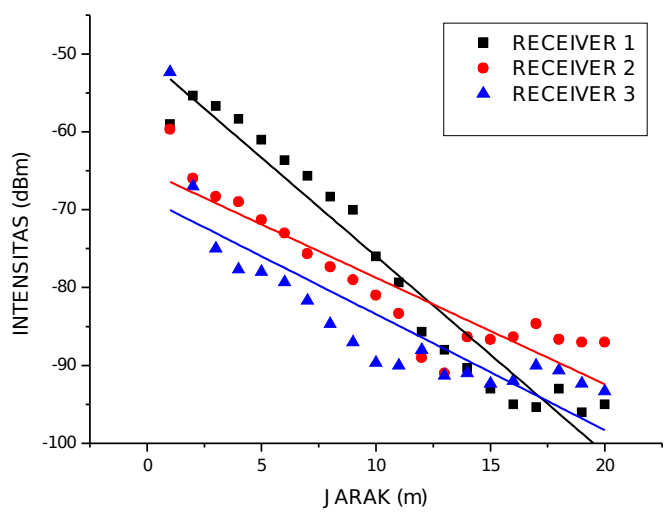

Gambar 7. Grafik karakteristik model 1 IPS berbasis wireless smartphone

Perbedaan daya terima intensitas sinyal Wi-Fi masingmasing receiver mungkin dikarenakan smartphone berasal dari vendor yang berbeda. Sehingga daya tangkap masingmasing smartphone terhadap sinyal Wi-Fi yang ditransmisikan berbeda. Ketika receiver saling berdekatan terjadi sedikit gangguan sehingga salah satu receiver tidak stabil pada jarak yang dekat dengan transmiter. Begitu juga ketika receiver mulai berada pada jarak yang cukup jauh, data menunjukkan kecenderungan yang berbeda. Semakin jauh jarak antara receiver dan transmiter maka intensitas sinyal yang terukur harus semakin lemah, namun yang terjadi pada jarak di atas $12 \mathrm{~m}$ sebagian data semakin kuat.

Grafik pada Gambar 7 dianalisis menggunakan regresi linier untuk mendapatkan persamaan linier masing-masing receiver yang ditunjukkan dalam Tabel 1. Persamaan yang didapatkan kemudian digunakan untuk menentukan jarak antara transmiter dan receiver berdasarkan intensitas sinyal yang diterima oleh receiver yang selanjutnya berfungsi sebagai input untuk menentukan posisi transmiter. 
Tabel 1. Persamaan linier model 1 IPS berbasis wireless smartphone

\begin{tabular}{cc}
\hline Receiver & Persamaan linier \\
\hline 1 & $I=-2,53 d_{i j}-50,70$ \\
2 & $I=-1,37 d_{i j}-65,06$ \\
3 & $I=-1,49 d_{i j}-68,55$ \\
\hline
\end{tabular}

Gambar 8 merupakan rekonstruksi hasil estimasi posisi berdasarkan intensitas sinyal Wi-Fi yang diterima oleh receiver. Pada gambar tersebut terdapat perbedan dengan posisi asli sebaran titik transmiter dalam area of investigation yang ditunjukkan pada Gambar 5. Perbedaan tersebut diindikasikan dengan bergesernya titik-titik transmitter hasil rekonstruksi. Model 1 IPS dapat merekonstruksi semua hasil estimasi posisi dengan tingkat kesalahan terkecil yaitu $2 \mathrm{~m}$ dan akurasi terbaiknya mencapai $89,47 \%$. Model 1 IPS memiliki rata-rata tingkat akurasi 76,51\% seperti ditunjukkan dalam Tabel 2 .

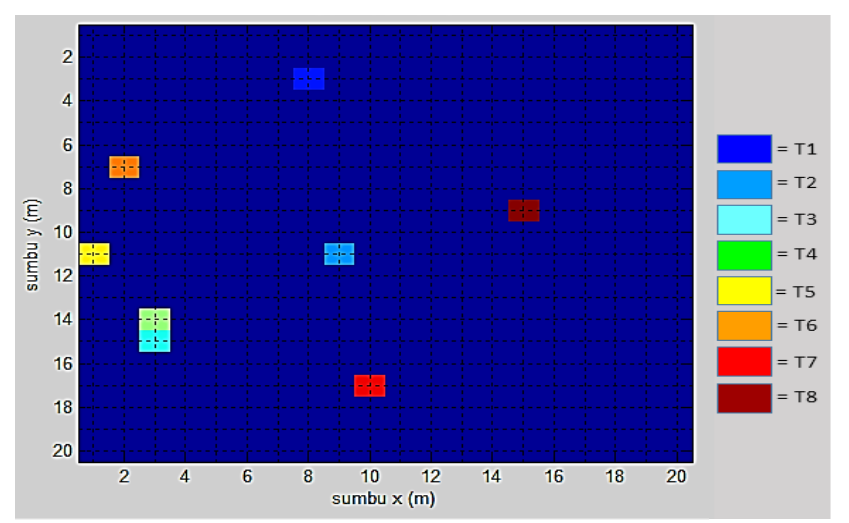

Gambar 8. Hasil rekonstruksi model 1 IPS berbasis wireless smartphone

Tabel 2. Evaluasi hasil rekonstruksi model 1 IPS berbasis wireless smartphone

\begin{tabular}{|c|c|c|c|c|c|}
\hline \multicolumn{2}{|c|}{$\begin{array}{c}\text { Real- } \\
\text { Position }\end{array}$} & \multicolumn{2}{|c|}{ Est-Position } & \multirow[t]{2}{*}{$\operatorname{Error}(\mathrm{m})$} & \multirow[t]{2}{*}{ Akurasi (\%) } \\
\hline$X$ & $\mathrm{Y}$ & $\mathrm{X}$ & Y & & \\
\hline 6 & 3 & 8 & 3 & 2,00 & 89,47 \\
\hline 10 & 8 & 9 & 11 & 3,16 & 83,36 \\
\hline 8 & 13 & 3 & 15 & 5,39 & 71,66 \\
\hline 8 & 15 & 3 & 14 & 5,10 & 73,16 \\
\hline 2 & 15 & 1 & 11 & 4,12 & 78,30 \\
\hline 2 & 11 & 2 & 7 & 4,00 & 78,95 \\
\hline 16 & 12 & 10 & 17 & 7,81 & 58,89 \\
\hline 14 & 5 & 15 & 9 & 4,12 & 78,30 \\
\hline \multicolumn{4}{|c|}{ Rata-rata } & 4,46 & 76,51 \\
\hline
\end{tabular}

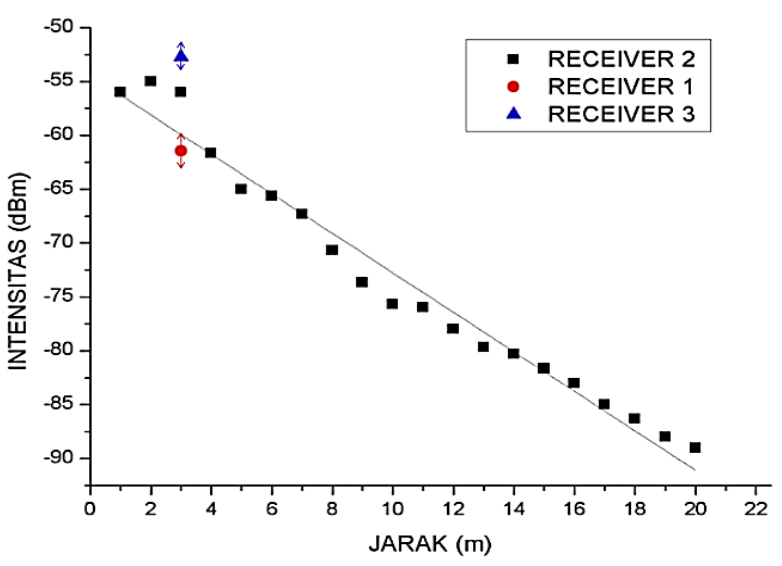

Gambar 9. Grafik karakteristik model 2 IPS berbasis wireless smartphone

Grafik pada Gambar 9 dianalisis menggunakan regresi linier untuk mendapatkan persamaan linier model 2 IPS berbasis wireless smartphone yang ditunjukkan pada Tabel 3. Persamaan linier yang didapatkan merupakan karakteristik masing-masing receiver. Persamaan ini digunakan untuk mendekati data hasil pengukuran yang kemudian digunakan untuk menentukan jarak antara receiver dan transmiter berdasarkan intensitas sinyal yang diterima oleh receiver.

Tabel 3. Persamaan linier model 2 IPS berbasis wireless smartphone

\begin{tabular}{cc}
\hline Receiver & Persamaan linier \\
\hline 1 & $I=-9,86^{13} d_{i j}+2,96^{14}$ \\
2 & $I=-1,83 d_{i j}-54,44$ \\
3 & $I=-3,59^{14} d_{i j}+1,08^{15}$
\end{tabular}

Rekonstruksi estimasi posisi model 2 berdasarkan intensitas sinyal Wi-Fi yang diterima oleh receiver direpresentasikan pada Gambar 10. Pada gambar tersebut dapat terlihat adanya perbedaan yang sangat signifikan antara posisi asli transmiter (Gambar 5) dengan posisi hasil rekonstruksi (Gambar 10 ). Model 2 hanya dapat merekontruksi lima hasil estimasi posisi dengan T2 dan T8 berada pada koordinat yang sama, sedangkan tiga estimasi posisi yang lain tidak dapat direkontruksi karena pada salah satu koordinat hasil estimasi bernilai nol dan negatif. Sehingga tiga hasil estimasi tersebut berada diluar jangakauan area of investigation yang telah ditentukan. 


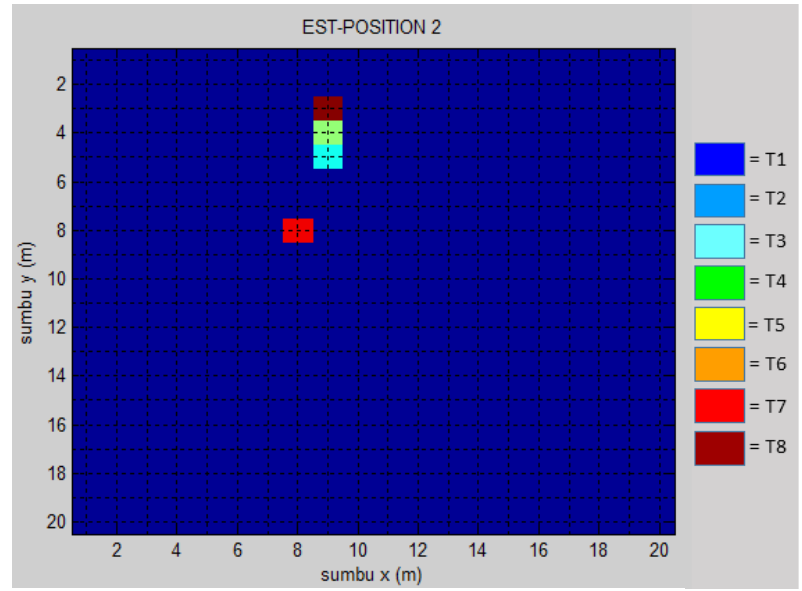

Gambar 10. Hasil rekonstruksi model 2 IPS

Evaluasi hasil rekonstruksi model 2 IPS ditunjukkan pada Tabel 4. Berdasarkan tabel tersebut model 2 dapat mengestimasi posisi dengan tingkat kesalahan yang besar yaitu 5,10 m. Untuk titik-titik yang lain tingkat kesalahan mencapai $16,55 \mathrm{~m}$. Rata-rata tingkat kesalahan IPS berbasis wireless smartphone dalam mengestimasi posisi model 2 ini sebesar 9,68 m. sedangkan untuk tingkat akurasi, model 2 hanya mampu mencapai tingkat akurasi $73,16 \%$. Rata-rata tingkat akurasi IPS model 2 paling bagus sebesar 49,03\%. Tingkat akurasi yang rendah ini dapat terjadi pada model 2 karena dalam rancangan model 2 hanya satu receiver (receiver 2) yang bergerak, sedangkan receiver 1 dan receiver 3 diam pada titik tertentu. Sehingga dua receiver tersebut tidak dapat mengakomodir distribusi sebaran intensitas sinyal Wi-Fi yang dipancarkan setiap perubahan pixel.

Tabel 4. Evaluasi hasil rekonstruksi model 2 IPS

\begin{tabular}{|c|c|c|c|c|c|}
\hline \multicolumn{2}{|c|}{$\begin{array}{c}\text { Real- } \\
\text { Position }\end{array}$} & \multicolumn{2}{|c|}{$\begin{array}{c}\text { Est-Position } \\
\text { Data } 1\end{array}$} & \multirow{2}{*}{$\begin{array}{c}\text { Error } \\
(\mathrm{m})\end{array}$} & \multirow{2}{*}{$\begin{array}{c}\text { Akurasi } \\
(\%)\end{array}$} \\
\hline$X$ & $\mathrm{Y}$ & $\mathrm{X}$ & $\mathrm{Y}$ & & \\
\hline 6 & 3 & 9 & -4 & 7,62 & 59,92 \\
\hline 10 & 8 & 9 & 3 & 5,10 & 73,16 \\
\hline 8 & 13 & 9 & 5 & 8,06 & 57,57 \\
\hline 8 & 15 & 9 & 4 & 11,05 & 41,87 \\
\hline 2 & 15 & 9 & 0 & 16,55 & 12,88 \\
\hline 2 & 11 & 9 & -2 & 14,76 & 22,29 \\
\hline 16 & 12 & 8 & 8 & 8,94 & 52,92 \\
\hline 14 & 5 & 9 & 3 & 5,39 & 71,66 \\
\hline \multicolumn{4}{|c|}{ Rata-rata } & 9,68 & 49,03 \\
\hline
\end{tabular}

\section{KESIMPULAN}

Model 1 IPS memiliki tingkat akurasi lebih baik dari pada model 2 IPS. Hal tersebut dibuktikan dengan rata-rata tingkat akurasi yang dimiliki model 1 IPS mencapai $76,51 \%$, sedangkan rata-rata tingkat akurasi yang dimiliki model 2 IPS hanya mampu mencapai $49,03 \%$.

\section{UCAPAN TERIMA KASIH}

Penulis menyampaikan terimakasih kepada Bapak Bowo Eko Cahyono dan Ibu Arry Yuariatun Nurhayati selaku dosen penguji yang telah banyak memberi masukan dan saran dalam penelitian ini.

\section{DAFTAR PUSTAKA}

[1] Astrini, R. dan P. Oswald. 2012. Modul Pelatihan Quantum GIS Tingkat Dasar: untuk Pemetaan Evakuasi Tsunami. Mataram: GIZ-Decentralization as Contribution to Good Govermance / BAPPEDA.

[2] El-Rabbany, A. 2002. Introduction to GPS: the Global Positioning System. Boston: Artech House, INC.

[3] Habibi, W dan A. M. Shiddiqi. 2011. Pembangunan Sistem Pelacakan Dan Penelusuran Device Mobile Berbasis Global Positioning Sistem (GPS) Pada Platform Mobile Google. Tesis. Surabaya. Teknik Informatika Institut Teknologi Sepuluh Nopember.

[4] Hu, B. 2013. Wi-Fi Based Indoor Positioning System Using Smartphones. Tesis. Melbourne. School of Mathematical and Geospatial Sciences Royal Melbourne Institute of Technology (RIMT) University.

[5] Mama, M. 2008. Matheatical Modelling of The Global Positioning System Tracking Signals. Tesis. Karlskrona: Departement of Mathematical Science Blekinge Institute of Technology.

[6] Perdana, F. H., R. V. Hari Ginardi, dan F. X. Arunanto. 2016. Implementasi Indoor Positioning System berbasis smartphone dengan penambahan Acces Point untuk Studi Kasus Gedung Teknik Informatika ITS. Jurnal Teknik ITS. 5(2): A336-A341.

[7] Putra, R. I. P., W. Wibisono, dan H. Studiawan. 2013. Sistem Pendeteksi Posisi dalam Ruangan Menggunakan Kekuatan Sinyal Wi-Fi dengan Penerapan Algoritma Cluster Filtered KNN. Jurnal Teknik Pomits. 2(1): 1-5.

[8] Rahayu, S. B. 2013. Perancangan Aplikasi Mobile Berbasis Android Tentang Pencarian Hotel dan Pom Bensin di Kota Bumiayu. Skripsi. Yogyakarta: Sekolah Tinggi Manajemen Informatika dan Komputer AMIKOM Yogyakarta.

[9] Tarrío, P., A. M. Bernardos, dan J. R. Casar. 2011. Weight Least Squares Techniques for Improved Received Signal Strength Based Localization. MDPI Sensors. 2011(11): 8569-8592.

[10] Wells, D., N. Beck, D. Delikaraoglou, A. Kleusberg, E. J. Krakiwsky, G. Lachapelle, R. B. Langley, M. Nakiboglu, K. P. Schwarz, J. M. Tranquilla, P. Vanicek. 1999. Guide to GPS Positioning. Fredericton, N. B.: Departement of Geodesy and Geomatics Engineering Uniersity of New Brunwick. 